UDC 678.046.3

\title{
TECHNOLOGICAL CHARACTERISTICS OF DRESSING LAYERED ALUMINOSILICATES PROCESS BY ORGANOSILICON COMPOUNDS
}

\author{
R.V. Kurbanova \\ Institute of Polymer Materials \\ National Academy of Sciences of Azerbaijan \\ 124, S.Vurgun str. AZ 5004, Sumgayit, Azerbaijan; e-mail: rena072@yandex.ru
}

Received 19.10.2019

\begin{abstract}
A principled technological scheme for fine-dispersed aluminosilicate dressing process with various types of organosilicon compounds, as well as technological characteristics of dressing and obtaining of modified aluminosilicates are shown. Kaolin, talc, quartz, clinoptilolite, montmorillonite, vesuvian, bentonite were used as aluminosilicates. Research into physicomechanical properties of polymer composites revealed that the loading of unmodified kaolin into low density polyethylene leads to a decrease in the elongation and ultimate tensile stress with a maximum at $10 \%$ wt. filler content.

However, the loading of $10 \% \mathrm{wt}$. of the dressed kaolin is accompanied by a noticeable improvement in the ultimate tensile stress, flexural strength of the composite in terms of elongation maintenance at a relatively high level. For a comparative properties' evaluation it showed the possibility of producing in principle dressed aluminosilicates with a wide range of organosilicon compounds. It went to show that out of 13 names of organosilicon compounds, chlorine-containing dressing sizes have a slight effect of enhancing the strength of composite materials.
\end{abstract}

Keywords: technology, dressing, layered aluminosilicate, organosilicon compounds, dryer, reactor.

DOI: 10.32737/2221-8688-2019-4-526-534

\section{Introduction}

The progress of engineering, shipbuilding, construction, military and space technology is accompanied by growing need in the development of new types of polymeric materials, composites, heat-shielding coatings to meet increased demand for these products. As a rule, the demand includes high strength, heat resistance, impact resistance capability, wear resistance, fire resistance, etc. [1-3]. For a long time, many scientists tried to solve this problem directly in the process of industrial synthesis of homo- and copolymers, by loading various modifiers, fillers, and compiling a mixture of bipolar polymers $[4$, 5]. However, the past 10-years intensive development of dressed composite production revealed new promising perspectives for targeted modification of industrial polymers. At the present stage, the problem of dressing mineral fillers and improving their compatibility with the help of polymer matrix is one of the important and concurrently littlestudied scientific areas. The study of the issue is further complicated by the lack of systematic research on the development of technological methods for dressing aluminosilicate fillers of plastics, although the use of aluminosilicate mineral fillers provides for wide range of changes in the operational properties of composite materials [6,7]. There are practically no studies in the literature on the development and study of the technological features of the dressing of natural aluminosilicate layered mineral fillers of plastics. This is especially true for aluminosilicate nanoparticles the interest in which is growing every year. Many researchers explain this as being due to the fact that nanoparticles are characterized by a more developed surface area which contributes to the creation of conditions for efficient flow of dressing and formation of covalent chemical bonds in the organic-inorganic system $[6,8]$.

Despite large reserves of mineral raw materials in Azerbaijan, no production of various types of fillers for modifying structure and properties of polymer composites has so far been established. Among the promising 
natural mineral fillers there are kaolin, clinoptilolite, vesuvian, talc, clay, montmorillonite, bentonite, etc.

In view of the foregoing, the aim of the work was to consider technological features of silicate production process of various types of dressed aluminosilicates.

\section{Experimental part}

As natural aluminosilicates, kaolin, clinoptilolite, vesuvian, bentonite and a mineral from the class of silicates, talc, were used. It should be noted that the considered minerals are among the layered aluminosilicates. A distinctive feature of the structure of particles of layered minerals is that various low molecular weight organic substances can migrate (intercalate) to the interlayer space with a subsequent decay of this structure into smaller structural formations.

Kaolin $\left(\mathrm{Al}_{2} \mathrm{O}_{3} \cdot 2 \mathrm{SiO}_{2} \cdot 2 \mathrm{H}_{2} \mathrm{O}\right)$-is white clay, consisting of the mineral kaolinite.

Talc $\left(3 \mathrm{MgO} \cdot 4 \mathrm{SiO}_{2} \cdot \mathrm{H}_{2} \mathrm{O}\right)$, TU-21-25-292 obtained from talcine rock. Talc was used in the work for comparison as a classic mineral filler for polymers.

Clinoptilolite (CTL) of the Aydag deposit of Azerbaijan, which typical oxide formula is $\left(\mathrm{Na}_{2} \mathrm{~K}_{2}\right) \mathrm{OAl}_{2} \mathrm{O}_{3} \cdot 10 \mathrm{SiO}_{2} \cdot 8 \mathrm{H}_{2} \mathrm{O}$ $\left(\mathrm{Na}_{2} \mathrm{~K}_{2}\right) \mathrm{OAl}_{2} \mathrm{O}_{3} \cdot 10 \mathrm{SiO}_{2} \cdot 8 \mathrm{H}_{2} \mathrm{O} . \mathrm{X}$-ray phase analysis of clinoptillolite showed that its composition mainly includes CTL - $70-75 \%$, kaolinite $-12 \%$, potassium feldspar $-3-5 \%$ and other impurities.

Bentonite - a mixture of natural aluminosilicate minerals, the basis of which is montmorillonite $\mathrm{Al}_{2} \mathrm{O}_{3} \cdot 4 \mathrm{SiO}_{2} \cdot \mathrm{nH}_{2} \mathrm{O}$ (60-70\%). In bentonites, kaolinite and other minerals are present. In bentonites, kaolinite and other minerals are present. Since montmorillonite predominates in the crystalline structure of bentonites, they are often called montmorillonites.

Vesuvian of the Gadabay deposit of Azerbaijan has the following composition: $\mathrm{Ca}_{10}(\mathrm{Mg}, \quad \mathrm{Fe})_{2} \mathrm{Al}_{4} \quad\left[\mathrm{SiO}_{4}\right]_{5} \cdot \quad\left[\mathrm{Si}_{2} \mathrm{O}_{7}\right]_{2}(\mathrm{OH})_{4}$ which was submitted by the head of the section of the Institute of Geology and Geophysics of the National Academy of Sciences of Azerbaijan, Academician Arif Ismailzade. Vesuvian contains 9.7 wt. \% kaolinite or layered nanoclay.

The following 13 organosilicon compounds were used as the dressing size:4,4dimethyl-1-methyldiethylsilyl-5-oxa-7,8-

epoxyoctane (I), 4,4-dimethyl-1methyldiethylsilyl-5-oxa-2-chloro-7,8-

epoxyoctane (II), 5-oxa-4-methyl-1methyldiethylsilyl-4-ethyl-7,8-epoxyoctane

(III), 5-oxa-4-methyl-1-methyldiethylsilyl-2chloro-4-ethyl-7,8-epoxyoctane (IV),4,4dimethyl-7-hydroxy-N- ( $\beta$-ethylamino) -1methyldiethylsilyl-5-oxoctylamine (V), 4,4dimethyl-7-hydroxy-N- ( $\beta$-ethylamino) -1methyldiethylsilyl-5-oxa-2-chloro-tylamine-8 (VI),N-allylamino-4,4-dimethyl-7-hydroxy-1methyldiethylsilyl-5-oxa-octylamine-8

(VII),N-allylamino-4,4-dimethyl-7-hydroxy-1methyldiethylsilyl-5-oxa-2-chlorooctyl-amine8(VIII), 2-Methyl-5-methyldiethylsilyl-2(methylenoxy-1,3-dioxolano)-pentane (IX), 2methyl-5-methyl-diethylsilyl-2- (methylenoxy1,3-dioxolano)-2-chloro-pentane (X), 4,4dimethyl-1-methyldiethylsilyl-5-oxa-7,8-

epitioooctane (XI), 4,4-dimethyl-1methyldiethylsilyl-5-oxa-2-chloro-7,8-

epitioooctane (XII) [9], as well as manufactured in the industry AGM-9, $\gamma$ aminopropyltriethoxysilane- $\quad \mathrm{H}_{2} \mathrm{NC}_{3} \mathrm{H}_{6^{-}}$ $\mathrm{Si}\left(\mathrm{OC}_{2} \mathrm{H}_{5}\right)_{3}$ (XIII).

Polymer composites based on low density polyethylene (LDPE) and kaolin were obtained in the process of mixing on rollers at a temperature of $155-160{ }^{\circ} \mathrm{C}$.

Ultimate tensile stress and elongation at break were determined in accordance with GOST 11262-80.

The heat resistance of the composites was determined by means of the Vicat method.

Melt flow index (MFI) was determined on a MELT FLOW TESTER, CEAST MF50 instrument (INSTRON, Italy) at a temperature of $190^{\circ} \mathrm{C}$. 


\section{Results and discussion}

The properties of silanes and their effectiveness in the zone of contact with functional groups of mineral particles were determined to comply with peculiarities of their molecular structure. Note that silicon is connected both with organofunctional (X) and silicon functional alkoxy groups (OR). In turn, silicon OR functional groups are typically alkoxy groups which in the first stage can be hydrolyzed in the presence of water. The reaction with water or moisture leads to the substitution of RO groups for hydroxyl to form silanols.<smiles>[R][R][Si]([Y])([R][R])O[R]</smiles>

After dissolution of organofunctional silanols in an aqueous solution, they are applied to the filler surface. It is characteristic that the functional groups $-\mathrm{Si}-\mathrm{OH}$ are very reactive and form a covalent bond between the filler particles containing $\mathrm{OH}-\mathrm{Me}$ and silanol.

Another important point that must always be kept under control is the influence of the $\mathrm{pH}$ of the medium on the rate of silane hydrolysis reaction At high and low $\mathrm{pH}$ values, the rate of hydrolysis reaction is many times higher than at neutral $\mathrm{pH}$. This is explained as being due to the fact that silane at a neutral $\mathrm{pH}$ value is the most stable. The dressing effect is most pronounced in the transition from neutral $(\mathrm{pH}=4)$ to acidic conditions $(\mathrm{pH}=3)$ as a result of which the rate of hydrolysis increases up to 50 times. The high sensitivity of the hydrolysis reaction to $\mathrm{pH}$ can be understood if we take into account the nucleophilic substitution mechanism during the hydrolysis of alkoxysilane in an acidic medium, since $\mathrm{H}^{-}$ ions directly affect the reaction rate [9].

It should be noted that organosilanes react with surface hydroxyl groups of mineral particles to form stable covalent bonds. The latter circumstance contributes to obtaining a stable monolayer of dressing size on the surface of filler particles. Consequently, the more hydroxyl groups on the surface of particles of aluminosilicate natural minerals, the more efficient the process of formation of a stable layer of a dressing size on them. It is clear that the process of forming a bond at the interface should be preceded by a certain stage of bringing the components of the mixture closer to a distance at which physical or physical-chemical processes can occur. As a result of such a rapprochement, depending on the type and composition of the polymer matrix, the formation of van-der-waals, hydrogen, coordination and covalent bonds becomes possible [9].

The first step in the silanol fixing process on the surface of the filler is performed under the influence of a hydrogen bond with the surface $\mathrm{OH}$ groups. If the water molecule is<smiles>[Y]CC[Si](O)(O)O[Si](O)(O)C[Y4]</smiles> 
not removed from the reaction zone, this reaction will be reversible. In addition, as long as there is a hydrogen bond, the silane can migrate to the surface of the filler. The covalent bond "silane-filler" $(\mathrm{Si}-\mathrm{O}-\mathrm{Me})$ actually fixes the silane on the surface of the filler. For example, the predisposition, in particular, of trialkoxysilane to selfcondensation contributes to the formation of a cross-linked structure of oligomeric type even before reaction with the surface groups of the filler [9].

Fig. 1 shows a principled technological scheme of the process of mineral mineral dressing by organosilicon compounds. As can be seen from this figure, the technological scheme consists of a reactor unit, where the process of dressing fine mineral disperse substance clinoptilolite occurs. The reactor unit includes 3 batch reactors (R-1, R-2, R-3). As the reactor is emptied, all reactors are sequentially connected to the dressing process: after dressing and emptying the first reactor, the second and then the third reactor is connected. At the beginning, distilled water is placed into the reactor using a pump $(\mathrm{P})$ from the container $(\mathrm{C}-1)$ which is heated up to $80^{\circ}$ $\mathrm{C}$, acidified with hydrochloric acid to $\mathrm{pH}=3$. From the calculation of $50 \mathrm{~kg}$ natural mineral to $100 \mathrm{~kg}$ of water a mixture is prepared. A fine powder of natural alumino-silicate with silanol is added through the second inlet of the reactor with constant stirring of the solution. The mixing process is carried out at relatively high speeds of rotation of the stirrer 400-500 rpm within 2 hours.

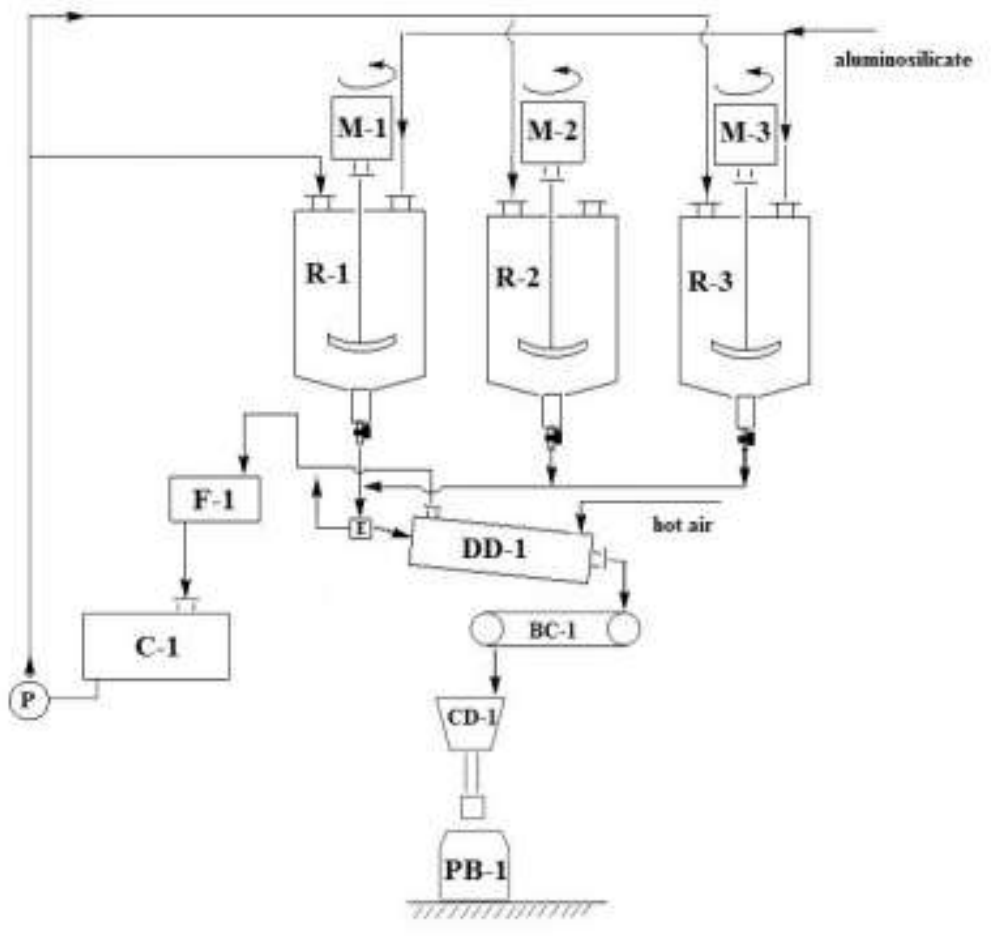

Figure 1. The principal technological scheme of the continuous process of dressing natural minerals with organosilicon compounds: (R-1, R-2, R-3)- dressing reactor, (M-1, M-2, M-3)asynchronous motor, (F-1) - fridge, (C-1)-container for distilled water, (E) - pre-drying extruder, (DD-1) - drum dryer, (BC-1) - belt conveyor, (CD-1)- container distributor dressed minerals, (PB-1) - packing bags for dressed minerals.

Thus, according to the technological scheme above, the dressing process consists of 4 main stages: 1) hydrolysis in reactor block; 2) extruder - dehydration at $100^{\circ} \mathrm{C}$; 3) desiccant - the last stage of dehydration; 4) bagging unit. In the reactor block, at a temperature of $70-80{ }^{\circ} \mathrm{C}$, the first stage of the process takes place - hydrolysis, as a result of which the ethoxy and methoxy groups of the dressing size are replaced by hydroxyl groups. 
The occurrence of hydroxyl groups contributed to the stage I of the dehydration reaction with the formation of covalent bonds between dressing size molecules and particles of the natural mineral.

After the first stage of the dressing process in the reactor, the solution enters the extruder (E), where the preliminary stage of water evaporation at $110^{\circ} \mathrm{C}$ takes place. In the extruder evaporates about $30-45 \%$ wt. of water. Next, the aqueous mixture of the mineral enters the reaction desiccant (DD-1), which is a horizontal type of rotating heated container. The desiccant is heated with hot air. In the dryer within 2 hours the completion of the 2nd stage of the dressing process takes place, accompanied by dehydration and complete drying of the dressed mineral. Water vapor from the dryer comes into the fridge (F1). From the fridge condensed water enters the backup container( $\mathrm{C}-1)$. In this case, the reversibility of the reaction is prevented and the process proceeds only in the direction of dehydration, followed by the completion of the formation of covalent bonds and the crosslinking of dressing size molecules to each other and with particles of the mineral.

Taking into account that the final part of the process of forming the dressed mineral proceeds in the reaction drying drum, we will consider the drying process in more detail. The drum slowly (5-7 turn / min.) rotates from the The axis of rotation of the drum is tilted at an angle of $5-6^{\circ}$, as a result of which the wet mineral entering the upper end of the drum, when it rotates, slowly moves along the cells towards the lower discharge end. Heat transfer agent can be flue gases or hot air heated to $110-120^{\circ} \mathrm{C}$.

In case where alumino-silicate nanoparticles are used, it is necessary to allow for the ability of these particles to be sprayed in an atmosphere of air in the course of introduction into the reactor. Therefore, we consider it necessary to emphasize that nanoparticles should be pre-moistened while being mixed with silanol and placed into the reaction medium through the second opening in the upper part of the reactor.

Drying drum (DD-1) in industrial processes is a welded metal cylinder the internal cavity of which serves as a drying space. It is installed with a bias towards the exit of the dried material. The drum dryer should operate at a constant temperature of the exhaust gases. When the humidity of the material or the intensity of its supply to the drum changes, the drying mode is regulated only by means of hot gases entering the drum; it is recommended to change the temperature of gases only to a minor extent. During this period, a slow and constant evaporation of the distilled water from the reaction medium occurred in the dryer. In these technological conditions when water as a result of evaporation was constantly removed from the reaction zone, the process of dressing and dehydration became irreversible. In other words, the final formation of a covalent bond at the interface of the dressing size-particle of an aluminosilicate proceeded in a drier. Water vapor enters the fridge (F-1), where it is condensed and drained into a reserve container (C-1) for water, for subsequent recycling. The dried dressed natural mineral enters the conveyor (BC-1), then to the distributor (CD$1)$, where the dressed filler is packed in bags (RB-1) weighing $20 \mathrm{~kg}$ each.

Using examples of kaolin and AGM-9 (XIII) dressing size, Table-1 provides results of study into the influence of the dressing process on basic physicomechanical properties of composites based on low density polyethylene (LDPE) and kaolin.

Table 1. Physical-mechanical properties of nanocomposites based on LDPE and kaolin

\begin{tabular}{|c|c|c|c|c|c|}
\hline №oo & $\begin{array}{c}\text { Composition of the } \\
\text { composite, \%wt. }\end{array}$ & $\begin{array}{c}\text { Ultimate tensile } \\
\text { stress, MPa }\end{array}$ & $\begin{array}{c}\text { Elongation at } \\
\text { break, \% }\end{array}$ & $\begin{array}{c}\text { Flexural } \\
\text { strength, MPa }\end{array}$ & $\begin{array}{c}\text { MFI, } \\
\text { g/10 min. }\end{array}$ \\
\hline 1 & LDPE & 14.3 & 525 & 11.6 & 1.03 \\
2 & LDPE+0.5D & 14.5 & 495 & 12.0 & 1.05 \\
3 & LDPE+1.0D & 14.9 & 465 & 12.2 & 0.99 \\
4 & LDPE+2.0D & 13.0 & 470 & 12.2 & 1.12 \\
\hline
\end{tabular}




\begin{tabular}{|c|c|c|c|c|c|}
\hline 5 & LDPE+3.0D & 12.2 & 310 & 10.5 & 1.53 \\
6 & LDPE+5K & 15.4 & 435 & 13.2 & 1.41 \\
7 & LDPE+10K & 16.3 & 110 & 14.8 & 2.18 \\
8 & LDPE+20K & 14.0 & 55 & 15.9 & 2.63 \\
9 & LDPE+30K & 12.2 & 25 & 16.7 & 1.96 \\
10 & LDPE+40K & 11.6 & 15 & 17.0 & 1.32 \\
11 & LDPE+5K+0.5D & 15.9 & 430 & 13.4 & 1.51 \\
12 & LDPE+5K+1.0D & 17.2 & 450 & 13.8 & 1.64 \\
13 & LDPE+5K+2.0D & 16.6 & 375 & 13.8 & 1.82 \\
14 & LDPE+5K+3.0D & 13.8 & 275 & 12.9 & 1.86 \\
15 & LDPE+10K+0.5D & 16.7 & 105 & 15.2 & 2.35 \\
16 & LDPE+10K+1.0D & 18.0 & 120 & 15.6 & 2.42 \\
17 & LDPE+10K+2.0D & 18.5 & 95 & 16.2 & 2.57 \\
18 & LDPE+10K+3.0D & 15.3 & 100 & 16.0 & 2.73 \\
19 & LDPE+20K+0.5D & 15.2 & 60 & 16.5 & 2.71 \\
20 & LDPE+20K+1.0D & 16.0 & 75 & 17.0 & 2.77 \\
21 & LDPE+20K+2.0D & 18.2 & 55 & 17.3 & 2.92 \\
22 & LDPE+20K+3.0D & 15.8 & 55 & 16.9 & 2.88 \\
23 & LDPE+30K+0.5D & 13.6 & 30 & 17.0 & 2.25 \\
24 & LDPE+30K+1.0D & 14.6 & 40 & 18.4 & 2.24 \\
25 & LDPE+30K+2.0D & 15.7 & 25 & 18.5 & 2.05 \\
26 & LDPE+30K+3.0D & 14.1 & 25 & 18.0 & 2.18 \\
27 & LDPE+40K+0.5D & 12.8 & 25 & 17.4 & 1.33 \\
28 & LDPE+40K+1.0D & 13.0 & 25 & 18.2 & 1.42 \\
29 & LDPE+40K+2.0D & 13.3 & 20 & 18.7 & 1.74 \\
30 & LDPE+40K+3.0D & 14.1 & 15 & 18.9 & 1.59 \\
\hline
\end{tabular}

${ }^{*} K$ - kaolin, $D$ - dressing size (XIII).

A comparative analysis of the data presented in this table, it can be established that as a result of dressing, a rather noticeable improvement in the strength characteristics of polymer composites was achieved. It is characteristic that the composite with 5\% wt. kaolin content the maximum value of ultimate tensile stress was obtained with the loading of $1.0 \%$ wt. dressing size. At the same time, the concentration of kaolin $10 \%$ wt. and higher maximum strengthening effect was reached with the loading of $2.0 \%$ wt. dressing size. A comparison with unapproved composites (samples 6-10) says that, in addition to the low value of strength properties, a sharp deterioration in the elongation at break of the composites under consideration was observed.

To conduct a comparative assessment, Table-2 lists the properties of polymer composites, where various types of dressed aluminosilicates are used as filler. Clinoptilolite, vesuvian, bentonite, talc were used as aluminosilicate. As can be seen from the Table 2, regardless of the type of aluminosilicate used, as a result of their dressing, there is a general tendency to increase the ultimate tensile stress and heat resistance of composite materials. At the same time, a certain decrease in the elongation at break and MFI of the dressed composites was found.

Table 2. Physical-mechanical properties of nanocomposites based on LDPE, clinoptilolite (ctl), vesuvian (vs) and bentonite (bt)

\begin{tabular}{|c|c|c|c|c|c|}
\hline №№ & $\begin{array}{c}\text { Composition of the } \\
\text { composite, \%wt. }\end{array}$ & $\begin{array}{c}\text { Ultimate tensile } \\
\text { stress, MPa }\end{array}$ & $\begin{array}{c}\text { Elongation at } \\
\text { break, \% }\end{array}$ & $\begin{array}{c}\text { Heat } \\
\text { resistance, } \\
{ }^{\circ} \mathrm{C}\end{array}$ & $\begin{array}{c}\text { MFI, } \\
\text { g/10 min. }\end{array}$ \\
\hline 1 & LDPE+10tl & 16.5 & 165 & 90 & 5.4 \\
\hline
\end{tabular}




\begin{tabular}{|l|c|c|c|c|c|}
\hline 2 & LDPE+10tl+1.0A & 18.0 & 120 & 93 & 2.4 \\
3 & LDPE+10ctl & 16.9 & 135 & 91 & 6.8 \\
4 & LDPE+10ctl+1.0A & 18.3 & 115 & 94 & 3.1 \\
5 & LDPE+10vs & 16.2 & 150 & 90 & 6.4 \\
6 & LDPE+10vs+1.0A & 18.6 & 130 & 93 & 3.7 \\
7 & LDPE+10bt & 16.0 & 165 & 89 & 5.7 \\
8 & LDPE+10bt+1.0A & 18.2 & 115 & 94 & 2.7 \\
\hline
\end{tabular}

Talc - tl, clinoptilolite - ctl, vesuvian - vs, bentonite - bt

Apparently, this circumstance is due to the fact that, first, the dressing of fine particles of aluminosilicates contributes to a significant reduction in the possibility of agglomeration of particles; secondly, as a result of the dehydration reaction, a covalent bond, a dressing size - aluminosilicate, a dressing size - dressing size is formed. The latter circumstance contributes to the formation of a micromesh structure of a dressing size on the surface of filler particles accompanied by an improvement in the compatibility and adhesive interaction of chemically modified mineral particles with a polymer matrix [10-12]. An increase in heat resistance and a decrease in the MFI of composite dressing materials in general is direct evidence to the formation of mesh structure. So, for example, according to the data in Tables 1 and 2, it found that the heat resistance of the dressed composite (LDPE $+10 \%$ wt. mineral $+1.0 \%$ wt. AGM9) was 93-94 ${ }^{\circ} \mathrm{C}$ while for undressed composites the value of heat resistance varies within $89-91^{\circ} \mathrm{C}$.

At the same time, as can be seen from Table-3, the type of dressing size used has a significant impact on the properties of composites. For example, chlorine-containing dressing sizes result in deterioration of the physicomechanical properties of composites. This circumstance makes it possible to argue about the need in selective approach to the selection of dressing agents.

Table 3. Effect of the type of organosilicon compounds on the properties of dressed composites based on LDPE + 10\% wt. kaolin + dressing size

\begin{tabular}{|c|l|c|c|c|}
\hline №oo & $\begin{array}{c}\text { Composition of the composite, } \\
\text { \%wt. }\end{array}$ & $\begin{array}{c}\text { Ultimate tensile } \\
\text { stress, MPa }\end{array}$ & $\begin{array}{c}\text { Elongation at } \\
\text { break, \% }\end{array}$ & $\begin{array}{c}\text { Flexural } \\
\text { strength, } \\
\text { MPa }\end{array}$ \\
\hline 1 & LDPE+10\%kaolin +2.0\% (XIII) & 18.5 & 95 & 16.2 \\
2 & LDPE +10\%kaolin +2.0\% (I) & 17.8 & 70 & 15.6 \\
3 & LDPE +10\%kaolin +2.0\% (II) & 15.3 & 45 & 14.0 \\
4 & LDPE +10\%kaolin +2.0\% (III) & 18.5 & 100 & 16.0 \\
5 & LDPE +10\%kaolin +2.0\% (IV) & 14.7 & 50 & 13.3 \\
6 & LDPE +10\%kaolin +2.0\% (V) & 17.9 & 90 & 15.4 \\
7 & LDPE+10\%kaolin +2.0\% (VI) & 13.6 & 55 & 12.9 \\
8 & LDPE+10\%kaolin +2.0\% (VII) & 17.3 & 95 & 15.8 \\
9 & LDPE+10\%kaolin +2.0\% (VIII) & 12.2 & 70 & 12.4 \\
10 & LDPE+10\%kaolin +2.0\% (IX) & 18.2 & 75 & 16.6 \\
11 & LDPE+10\%kaolin +2.0\% (X) & 14.5 & 45 & 11.9 \\
12 & LDPE+10\%kaolin +2.0\% (XI) & 18.3 & 95 & 16.6 \\
\hline
\end{tabular}

The low efficiency of halogen-containing dressing size action is, apparently, due to the fact that the presence of chlorine in the composition of the organosilicon component leads to the deterioration of adhesion at the phase-particle-dressing size interface and hindered crosslinking as a result of the sol-gel reaction. In addition, we do not rule out the possibility of slowing down the process of metal oxide hydrolysis in the presence of chlorine-containing dressing size. Apparently, in this case it would be appropriate to argue 
about the selectivity of dressing size in improving the properties of polymer composites.

Based on the foregoing, it can be concluded that the technological procedures embrace technological process considers the entire process of dressing fine-dispersed aluminosilicate particles. The effect of various types of dressing size on the properties of LDPE and aluminosilicates-based composite materials is shown. It found that chlorinecontaining dressing sizes have a smaller effect on the strengthening of composite materials.

\section{References}

1. Simonov-Emelyanov I.D. Principles of creation and processing of composite materials of dispersed structure. Plasticheskie massy - Plastics. 2005, no. 1, pp.11-16. (In Russian).

2. Prut E.V., Zeleneckij A.N. Chemical modification and blending of polymers in an extruder-reactor. Uspekhi himii Russian Chem.Rev. 2001, vol.70, no. 1, pp.72-87.

3. Kravchenko T.P., Ermakov S.N., Kerber M.L. and etc. Scientific and technical problems of obtaining composite materials based on structural thermoplastics. Plasticheskie massy - Plastics. 2010, no. 10, pp. 32-37. (In Russian)

4. Kakhramanov N.T., Gusejnova Z.N., Gasanova A.A., Allahverdieva H.V., Mustafaeva F.A., Osipchik V.S. Reactive extrusion of dynamic elastoplastics on the basis of thermoplastic polyolefins and butyl rubber. Chemical Problems. 2019, no. 2, pp. 267-274.

5. Prut E.V. Thermoplastic elastomers: innovation and potential. Innovatika $i$ ekspertiza-Innovation and expertise. 2013, no.1 (10), pp.68-75. (In Russian)

6. Pomogajlo A.D.Hybrid polymer-inorganic nanocomposites.Uspekhi himii-Chemistry advances. 2000, vol.69, no. 1, pp.60. (In Russian)

7. Kakhramanov N.T., Gasimova G.Sh., Pesetsriy S.S., Kakhramanly Y.N.,Gurbanova R.V. Physical and mechanical properties of nanocomposites based on block copolymer propylene with ethylene and graphite. Chemical problems. 2019, no. 1, pp.72-80.

8. Kakhramanov N.T., Kurbanova R.V., Kahramanly YU.N., Mamedli U.M., CHernyavskaya N.A. Dressed nanocomposites based on LDPE and quartz. Plasticheskie massy-Plastics. 2018, no. 56, pp.37-40. (In Russian).

9. Kurbanova R.V., Kakhramanov N.T., Kakhramanly Y.N., Mammadova G.M. About mechanism of dressing of surface of mineral fillers of plastics. Problems and their solutions. Processes of petrochemistry and oil refining. 2018, no. 4, pp. 389-396.

10. Lyamkin D.N., Skroznikov S.V., Zhemerikin A.N. The influence of the crosslinking method on the stability of the chemical mesh of polyethylene insulation of cable products under thermomechanical effects. Plasticheskie massy-Plastics. 2012, no. 2, pp. 25-28. (In Russian).

11. Ulitin N.V., Deberdeev T.R. Some viscoelastic properties of densely crosslinked polymers. Theoretical calculation. Plasticheskie massy-Plastics. 2012, no. 2, pp.34-39. (In Russian)

12. Petunova M.D., Ezernickaya M.G., Piminova K.S., Kravchenko T.P., Aristov V.M., Maceevich T.A., Askadskij A.A. Study of the properties of polymerinorganic hybrid composites. Plasticheskie massy-Plastics. 2018, no. 34, pp.3-8. (In Russian). 


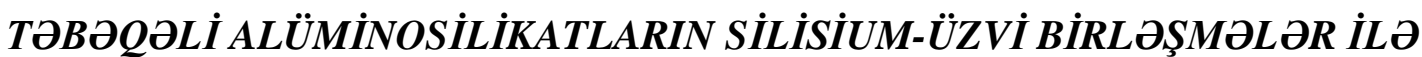 APPRETLOSDIRMOPROSESININ TEXNOLOJI XÜSUSIYYOTLORI
}

\author{
R.V. Qurbanova
}

AMEA-nın Polimer Materialları Institutu

AZ 5004, Sumqayıt ş, S.Vurğun küç. 124, e-mail: rena072@yandex.ru

\begin{abstract}
Maqaladə müxtəlif növ silisium-üzvi birlaşməlar ila xırdadispersli alüminosilikatların appretlaşdirmə prosesinin prinsipial texnoloji sxemi təqdim olunmuşdur. Modifikasiya olunmuş alüminosilikatların alınması va appretlaşdirilməsinın texnoloji xüsusiyyatlori göstarilmişdir. Alüminosilikatlar olaraq kaolin, talk, kvars, klinoptilolit, montmorillonit, vezuvian, bentonit istifada olunmuşdur. Polimer kompozitlarin fiziki-mexaniki xüsusiyyatlarinin tadqiqi naticasinda müəyyən olunmuşdur ki, aşağı sıxlıqlı polietilen tərkibina modifikasiya olunmamış kaolinin daxil edilməsi maksimum 10 kütla \% doldurucunun miqdarında nisbi uzanmanın va dartılmada möhkamlik haddinin azalmasına sabəb olur. Lakin, 10 kütla \% appretlaşdirilmiş kaolinin daxil edilməsi kompozitin nisbi uzanmanın nisbətən yüksək səviyyədə saxlanılması ila dartılmada möhkəmlik həddinin və ayilməyə qarşı davamlılığının nəzərəçarpacaq daracadə yaxşılaşması müşayiat olunur. Xüsusiyyatlarin müqayisali qiymatlandirlməsi üçün geniş çeşidda silisium-üzvi birloşmalarda istifado olunaraq appretlaşdirilmiş alüminosilikatların prinsipial alınmasının mümkün olduğu göstərilir. 13 silisium-üzvi birlaşmədən xlortərkibli appretlarin kompozit materialların möhkamliyinin artımına daha az tasir göstardiyi müəyyən olunmuşdur.

Açar sözlor: texnologiya, appletlaşdirmə, təbəqali alüminosilikat, silisium-üzvi birlaşmə, quruducu, reaktor.

\section{ТЕХНОЛОГИЧЕСКИЕ ОСОБЕННОСТИ ПРОЦЕССА АППРЕТИРОВАНИЯ СЛОИСТЫХ АЛЮМОСИЛИКАТОВ КРЕМНИЙОРГАНИЧЕСКИМИ СОЕДИНЕНИЯМИ}

\section{Р.В. Курбанова}

Институт полимерных материалов Наџиональной АН Азербайджана AZ5004, г.Сумгайылт, ул. С.Вургуна 124, e-mail: rena072@yandex.ru

Приводится принципиальная технологическая схема процесса аппретирования мелкодисперсных алюмосиликатов с различными типами кремнийорганических соединений. Показаны технологические особенности аппретирования и получения модифицированных алюмосиликатов. В качестве алюмосиликатов использовали каолин, тальк, квари, клиноптилолит, монтмориллонит, везувиан, бентонит. В результате исследования физико-механических свойств полимерных композитов было установлено, что введение немодифицированного каолина в состав полиэтилена низкой плотности приводит $\kappa$ снижению относительного удлинения $u$ разрушающего напряжения с максимумом при 10\%масс. содержании наполнителя. Однако введение 10\%масс. аппретированного каолина сопровождается заметным улучшением разрушающего напряжения, прочности на изгиб композита при сохранении относительного удлинения на сравнительно высоком уровне. Для сопоставительной оиенки свойств показана принципиальная возможность получения аппретированных алюмосиликатов с использованием широкого набора кремнийорганических соединений. Установлено, что из числа 13 наименований кремнийорганических соединений, хлорсодержсащие аппреты оказывают незначительный эффект усиления прочности композитных материалов.

Ключевые слова: технология, аппретирование, слоистый алюмосиликат, кремнийорганические соединения, осушитель, реактор 